\title{
Inhalt
}

\section{Institutional Responses to Religious Diversity}

\section{Guest Editors: Astrid Mattes, Julia Mourão Permoser, Kristina Stoeckl}

Astrid Mattes / Julia Mourão Permoser / Kristina Stoeckl

Introduction: Institutional Responses to Religious Diversity . . . . . . 2

Christine Brunn

How Integration Policies have Discovered Religion: German, French and British Politics within the Scope of a Comparative Institutional

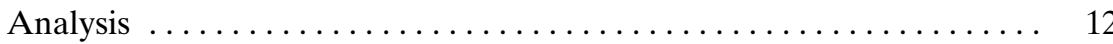

Julia Martínez-Ariño / Mar Griera

Responses to Religious Diversity in Spain: Hospitals and Prisons from a Comparative Perspective . . . . . . . . . . . . . . . . . . . . . . . 37

Andrea Rea

Coping with the Training of Muslim Leaders in Belgium . . . . . . . . . 60

Wolfram Reiss

Der Umgang mit religiösen Minderheiten in der österreichischen Armee 83

Regina Polak

Religiöse Diversität als Herausforderung für die Katholische Kirche . . . 115

\section{Open Section}

Karsten Lehmann

Religiöse Sedimente im Menschenrechtsdiskurs. Zur Dynamik der

Konstruktionen „des Religiösen“ und „des Säkularen“ ........... . 144 